\title{
The Stein Brothers Are in Town (Ve městě jsou bratři Steinové)
}

\author{
Author: Věra Kalábová
}

First Published: 1967

About the Author: Věra Kalábová (1932-1993) was born in New York City. She spent her childhood in Slovakia. In 1958, she started working at the Prague Film Studio Barrandov as a producer and screenwriter. In the 1960s she took part in the production of well-known films, also with the Holocaust topics, like The Fifth Horseman Is Fear (1964; $\rightarrow$ Without Beauty, without a Collar), I, Justice (1967) or $\rightarrow$ The Cremator (film 1969, novel 1967).

The novel The Stein Brothers Are in Town, which was positively accepted by critics, was her debut. Her second novel The Present Time of Past Things (1969, Přítomný čas věcí minulých) presents topics of guilt and responsibility, similar to The Stein Brothers Are in Town. Kalábová also wrote TV dramas and radio plays.

\section{Content and Interpretation}

The novel is set in a small unnamed town in West of Slovakia on the border with Moravia. The actual time of narration is situated about 20 years after World War II. Nevertheless, the key events have happened during the war and readers learn about them in flashbacks. The novel is narrated in the third person with alternated and limited points of view. There are two main characters, Hrebíček and Benčo.

The first one is Jozef Hrebíček, a decent but restrained man, an opponent to fascism and the clerofascist Slovak regime. Up until the local Jews' deportation, he was friendly with two of the Jewish inhabitants of the town, the Stein brothers. Imrich Stein was a butcher, his younger brother Hans a medical student. In December 1942, during the night when the Jews from the town were transported to Auschwitz, Hrebíček saw the preparation of this deportation from a distance. The next day he found a witness, a Hungarian woman Néryová, who had a bad reputation of being a "trollop". From her window, she watched the Slovak guardsmen bringing the Jews to the square, searching them for their valuables and also brutally beating and stabbing both of the Stein brothers. She recognised eight Slovak Hlinka guardsmen from the town. After the war, nobody from the local Jews returned home. Hrebíček swore revenge and testified against the guardsmen in court. However, only one of the eight men was convicted, the others fled or avoided the punishment. Mrs Néryová refused to testify. Public opinion condemned Hrebíček because he testified against "our people”, he was sarcastically called the Avenger.

The second of the two main characters is Ferdinand Benčo. He is Hrebíček's antagonist, an ambitious teacher who became an important official of the Hlinka Guard and director of the school during the clerofascist regime. He was involved in the beating and robbing of deported Jews. Thanks to Hrebíček's testimony, he has been sen- 
tenced to four years in prison. After his release, he is bitter and hates the current Czechoslovak regime. He has endured several heart attacks, is almost helpless, and dependent on his wife.

Now, at the time of narration in the 1960s, a message comes that both Stein brothers are returning to town. The past is unexpectedly coming back to haunt them. Some inhabitants of the town are afraid, because they have stolen Jewish property. See Jana Juráňová's $\rightarrow$ A Pending Matter or Radka Denemarková's $\rightarrow$ Money from Hitler. They have brutally beaten and almost even killed both brothers to learn where they had had their gold and valuables. On the other hand, Hrebíček and a few others expect the Stein brothers to bring justice at last.

Finally, the message of the Steins' arrival turns out to be false. The alleged Steins will prove to be distant relatives of the town's inhabitants coming from Australia.

\section{Main Topics and Problems}

At the beginning of the novel, there is a motto, the quote written by the Italian political philosopher Niccolò Machiavelli in the 16th century: "If an injury has to be done to a man, it should be so severe that his vengeance need not be feared" (Kalábová, 1967, p. 5).

The themes of the novel are crime, guilt, revenge and justice. The first sentence (as well as the title of the work) reads "The Stein brothers are in town" (p. 5). Hrebiček and everybody in town assume the Steins will seek revenge for the injustice done to them. So a dramatic story unfolds. The use of this narrative device can be similar to adventure novels or films, mainly to so-called revenge stories (The Mark of Zorro, 1920; American or Italian westerns like High Noon, 1953; Once Upon a Time in the West, 1968 etc.). Here, a lonely honest man is fighting against villains who have committed a crime.

However, unlike adventure films or westerns, Věra Kalábová's story does not end with the retribution, victory of justice and defeat of criminals. One of the last scenes can even be seen as an ironic allusion to westerns' quick-draw duels: while Hrebíček is riding a bicycle he meets his opponent Benčo who wants to hide, but has a heart attack. Benčo’s wife asks Hrebíček for help and he brings Benčo to the hospital.

Also the distribution of positive and negative characters is not as clear as in westerns or criminal stories. Hrebíček, the "Avenger”, is an honest man but he doesn't have courage enough to hide a radio which the Steins entrust him, or to go to the mountains to fight against the fascists. The only one who defends the innocence of Jews in public, is the Catholic chaplain Majer. After the deportation of the Jews, he preaches about Cain and Abel, and compares Abel's killing with the fate of the Jews. Majer is punished, and sent to the Eastern Front. He later gives up his priesthood and leaves town.

After the war, former guardsmen and fascists, apologise for their inhuman actions: "We didn't invent the transporting of the Jews. That was the law. Today there are different laws, we obey them again, that's all what a little man can do...” (p. 51). 
This argument about the powerlessness of a little man appears often in Czech or Slovak novels about the Holocaust, e.g. Dominik Tatarka's $\rightarrow$ The Clerical Republic, Hana Bělohradská's $\rightarrow$ Without Beauty, without a Collar or Ladislav Grosman's $\rightarrow$ The Shop on Main Street. As the narrator of The Stein Brothers Are in Town states, guilt slowly moves from the muddy small Slovak town to Nuremberg.

After the war, the little men mostly adapted to the new standards. People argued, the Jews were rich and exploited poor Slovaks. Former fascists have prominent offices and positions again. So Janek Klapáč, a member of the Fascist Hlinka’s Youth, denounced his neighbours during the war, for instance Hrebíček because he did not contribute to Winterhilfe for Nazi soldiers. Klapáč later made a career for himself in the Communist regime.

The author knew the Slovak society and mentality very well. It is also manifested in some Slovakisms in the Czech text ("hradská” / road; "hladný” / hungry).

\section{Cited Work}

Kalábová, V. (1967) Ve městě jsou bratři Steinové. Praha: Mladá fronta.

\section{Further References}

Fuks, L. (1967). Můj tip. Literární noviny, 16(35), p. 2. Hájková, A. (1967). Ve městě jsou bratři Steinové. Impuls, 3(2), p. 132. Lopatka, J. (2005). Posudky, ed. M. Špirit. Praha: Torst, pp. 280-281. Maixnerová, J. (2011). Reflexe židovství v prozaické tvorbě českých spisovatelek Hany Bělohradské a Věry Kalábové. Master Degree Thesis. Olomouc: Palackého univerzita. Nový, P. (1992). O velkém zlu v malém městě. MF Dnes, 16. 3., p. 6. Petříček, M. (1992). Ve městě jsou bratři Steinové. Literární noviny, 3(35), p. 5. Píša, V. (1992). Dva muži ve městě. Tvar, 3(24), p. 10. Vlašín, Š. (1967). Příběh procitlého svědomí. Rudé právo, 17. 8., p. 5. 